\title{
NUTRITIONAL STATUS OF SCHOOL GOING CHILDREN (6-15 YEARS) IN A SEMI-URBAN AREA OF CACHAR DISTRICT, ASSAM
}

\author{
Ajit Kumar Dey1, Ajoy Bhusan Nath ${ }^{2}$ \\ ${ }^{1}$ Assistant Professor, Department of Community Medicine, Silchar Medical College, Silchar, Assam. \\ ${ }^{2}$ Assistant Professor, Department of Community Medicine, Silchar Medical College, Silchar, Assam.
}

\section{ABSTRACT}

\section{BACKGROUND}

The foundation of adequate growth and development is laid before birth, during childhood, and is followed during adolescence. Nutritional status is an important index for measuring quality of life especially in children. In this respect, understanding the nutritional status of children has far reaching implications on better development of future generations as well as future development of humanity. Malnutrition and diet are by far the biggest risk factors for the global burden of disease.

\section{MATERIALS AND METHODS}

A cross-sectional study was conducted to understand the malnutrition scenario among the rural school children of 6-15 years age group and interplay of different sociodemographic factors contributing to it. Anthropometric data were analysed using WHO Anthro Plus version 1.0.4 software for assessing the growth of the children and by using appropriate statistical methods.

\section{RESULTS}

The mean height of boys and girls of the study group was lower than WHO 2007 standards in all age groups. Of the 216 school children, 53, 31 and 111 were stunted/severely stunted, underweight/severely underweight, and thin/very thin, respectively. Both univariate and multivariate analysis revealed different associated sociodemographic factors contributing to poor nutritional status of children such as low socioeconomic status and poor educational background of their parents $(\mathrm{p}<0.05)$.

\section{CONCLUSION}

The causes of malnutrition are not only recent but also long term deprivation resulting to chronic malnutrition. Malnutrition results from the interaction of poor-quality diets and poor-quality health and care environments and behaviours, so urgent steps should be taken to improve nutritional status of school children.

\section{KEYWORDS}

School Children, WHO Reference Standard, Adolescent, Malnutrition.

HOW TO CITE THIS ARTICLE: Dey AK, Nath AB. Nutritional status of school going children (6-15 years) in a semi-urban area of Cachar district, Assam. J. Evolution Med. Dent. Sci. 2017;6(54):4057-4062, DOI: 10.14260/Jemds/2017/877

\section{BACKGROUND}

Poor nutrition starts before birth, and generally continues into adolescence and adult life and can span generations. Chronically malnourished girls are more likely to remain undernourished during adolescence and adulthood, and when pregnant, are more likely to deliver low birth-weight babies.[1] Nutritional status is an important index for measuring quality of life especially in children. In this respect, understanding the nutritional status of children has far reaching implications on better development of future generations ${ }^{[2]}$ as well as future development of humanity.[3] School age is a dynamic period of physical growth as well as of mental development of the child.[2] During the adolescent growth spurt, body requires lot of nutrients which should be stored in the body during childhood and if body stores are deficient it can result in adverse health consequences like

Financial or Other, Competing Interest: None.

Submission 28-05-2017, Peer Review 23-06-2017,

Acceptance 29-06-2017, Published 06-07-2017.

Corresponding Author:

Dr. Ajit Kumar Dey,

Assistant Professor,

Department of Community Medicine,

Silchar Medical College,

Silchar, Assam, India.

E-mail: drajit.smc@gmail.com

DOI: $10.14260 /$ jemds $/ 2017 / 877$ growth retardation, scholastic backwardness and reduced work capacity.[4] Malnutrition manifests itself in many different ways: as poor child growth and development; as individuals who are skin and bone or prone to infection; as those who are carrying too much weight or who are at risk of chronic diseases because of excess intake of sugar, salt, or fat; or those who are deficient in important vitamins or minerals. Malnutrition and diet are by far the biggest risk factors for the global burden of disease: every country is facing a serious public health challenge from malnutrition. The economic consequences represent losses of 11 percent of gross domestic product (GDP) every year in Africa and Asia, whereas preventing malnutrition delivers $\$ 16$ in returns on investment for every $\$ 1$ spent.[5]

In adolescence, a second period of rapid growth [Fig. 1] may serve as a window of opportunity for compensating for early childhood growth failure, although the potential for significant catch-up is limited. Research evidence suggests that optimal nutrition during the brief period of pre-pubertal growth spurt, some 18 to 24 months immediately preceding menarche, results in catch-up growth from nutritional deficits suffered earlier in life.[6]

Studies addressing undernutrition are mostly restricted to under-5 populations, whereas very few studies have addressed school-going children to assess the magnitude of the problem. Hence, the present study was conducted to 
understand the malnutrition scenario among the school children of 6-15 years age group in Cachar district of Assam.

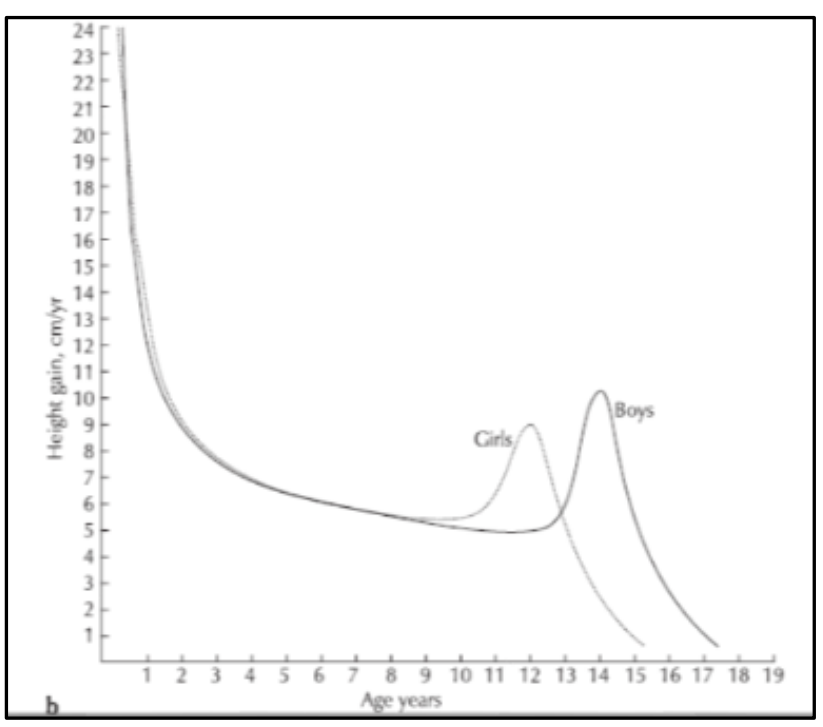

Figure 1. Source: Tanner J. Growth at Adolescence. Oxford: Blackwell Press, 1962.

1. To assess the nutritional status of rural school-going children of age group 6-15 years in Cachar district, Assam.

2. To study the interplay of different sociodemographic variables associated with the nutritional status.

\section{MATERIALS AND METHODS}

The present study was undertaken after ethical approval was obtained from the Institutional Ethics Committee of Silchar Medical College, Silchar. Study design adopted was a crosssectional study. The sample size was calculated as 190 by using the formula: $n=Z^{2} P Q / D^{2}$ Where: $n=$ minimum sample size $\mathrm{Z}=1.96 . \mathrm{P}=45 \%,{ }^{[7]}$ absolute precision of $10 \%$ at $95 \%$ confidence interval with a design effect of 2 .

The method of multistage sampling was used. There are 8 education blocks in Cachar district out of which Udharbond education block was selected randomly. Following which 3 government upper primary schools located nearby Silchar town were selected conveniently from total of 23 upper primary schools having total enrolment of 904 students. All children in the age group of 6-15 years of both sexes in these schools were included in the study.

They were divided into three groups 6-9 years, 9-12 years, 12-15 years by stratified random sampling. Total of 216 students were recruited for the study. For participation of the study subjects, parents/guardians were informed about the study objectives and verbal consent was obtained prior to inclusion in the study.

General information was collected by using a predesigned pretested questionnaire. Anthropometric measurements such as weight and height were recorded by using standard operating procedures. Weight was measured in a standard weighing (Bathroom). Weighing scale was calibrated every time before a new measurement was taken. Height was measured to the nearest $0.1 \mathrm{~cm}$ with no stretchable tape which was fixed to a vertical smooth wall and the subject was asked to stand erect without footwear on a firm/level surface with his/her back against the wall, feet parallel, and hands hanging by the sides. Each measurement was done twice and the average of the two readings was recorded.

After collection, all data entered in Microsoft excel 2007 and analysed by suing Statistical Package for Social Sciences (SPSS) software version 16.0 and appropriate statistical tests were applied. For quantitative data like height, weight, mean and standard deviation was calculated and compared with WHO reference values. The group comparisons for the categorical variables were analysed using Chi square test. The group comparison for quantity variables were analysed using two tailed independent student $t$ test.

Multiple logistic regression analysis was used and odds ratio calculated to find the strength of association. The $p$ value of less than 0.05 was considered as statistically significant. For nutritional assessment, Z-scores of BMI for age, height for age and weight for age were computed and used to assess thinness/overweight/obesity, stunting and wasting respectively using the WHO new reference values for school boys and girls.

\section{Anthropometric Data were Analysed using WHO Anthro Plus Version 1.0.4 Software for Assessing the Growth of the Children. The children were classified using the following Categories-}

1. Stunting (chronic undernutrition) is defined as a low height for age. Children with z scores (HAZ) $<-2$ are considered as stunted and those with $\mathrm{HAZ}<-3$ are severely stunted.

2. Underweight (mixed acute and chronic undernutrition) is defined as a low weight for age. Children with z scores (WAZ) $<-2$ are considered as underweight and those with $\mathrm{WAZ}<-3$ are severely underweight.

3. Thinness (measure of body fat) is defined as a low body mass index. Children with $\mathrm{z}$ scores (BMIZ) $<-2$ are considered as thin and those with BMI $<-3$ are severely thin.

\section{RESULTS}

Overall 216 school children of age group between 6 and 15 years were surveyed. Majority of the study subjects were girls $(62.5 \%)$ and the rest were boys (37.5\%). Among the study subjects, similar distribution of higher percent of girls comparable to boys was reported by other authors. ${ }^{[8]}$

Mean age with standard deviation (SD) of girls and boys was $11.32 \pm 2.18$ yrs and $11.17 \pm 2.17$ yrs. respectively. Mean weight with standard deviation (SD) of girls and boys was $27.84 \pm 7.54 \mathrm{~kg}$ and $26.07 \pm 7.92 \mathrm{~kg}$ respectively. The mean height (with SD) of the girls was $136.64 \pm 11.68 \mathrm{~cm}$, whereas that of boys was $134.08 \pm 12.02 \mathrm{~cm}$. In the present study, the BMI was found to be $19.6 \pm 3.6$ and $20.8 \pm 3.9$ in boys and girls respectively in the age group of 10-14 years.

Table 1 shows that the mean weight of girls were more than the boys except for the age group of $7,14,15$. Similar observation was reported by other authors.[9,10,11] The figures 2 and 3 show that the mean height of boys and girls of the study group was lower than WHO 2007 standards in all age groups. 


\begin{tabular}{|c|c|c|c|c|c|}
\hline $\begin{array}{c}\text { Age/ } \\
\text { Years }\end{array}$ & \multirow{2}{*}{ Sex } & Mean & Standard & $\begin{array}{c}\text { Mean } \\
\text { Weight }\end{array}$ & $\begin{array}{c}\text { Standard } \\
\text { deviation }\end{array}$ \\
\cline { 3 - 5 } 6 & $\mathrm{M}$ & 113.5 & 4.9 & 17.2 & 4.09 \\
\hline & $\mathrm{F}$ & 114.3 & 2.5 & 18.7 & 1.53 \\
\hline 7 & $\mathrm{M}$ & 115.1 & 5.01 & 17.8 & 2.76 \\
\hline & $\mathrm{F}$ & 116.4 & 4.8 & 15.8 & 0.76 \\
\hline 8 & $\mathrm{M}$ & 115 & 4.08 & 17 & 2.58 \\
\hline & $\mathrm{F}$ & 119.9 & 5 & 18.9 & 2.18 \\
\hline 9 & $\mathrm{M}$ & 124 & 1.22 & 20.5 & 0.71 \\
\hline & $\mathrm{F}$ & 123.7 & 5.62 & 20 & 1.58 \\
\hline 10 & $\mathrm{M}$ & 126.5 & 6.77 & 21.2 & 2.91 \\
\hline & $\mathrm{F}$ & 132.2 & 7.44 & 23.9 & 4.41 \\
\hline 11 & $\mathrm{M}$ & 132.9 & 6.29 & 23.4 & 3.27 \\
\hline & $\mathrm{F}$ & 135.4 & 7.98 & 25.3 & 4.15 \\
\hline 12 & $\mathrm{M}$ & 140.9 & 6.3 & 29.8 & 6.07 \\
\hline & $\mathrm{F}$ & 142.1 & 8.49 & 32.3 & 7.74 \\
\hline 13 & $\mathrm{M}$ & 142.8 & 9.14 & 31.6 & 7.06 \\
\hline & $\mathrm{F}$ & 143.8 & 7.79 & 31.8 & 4.98 \\
\hline 14 & $\mathrm{M}$ & 146.3 & 5.62 & 36 & 7.6 \\
\hline & $\mathrm{F}$ & 143.3 & 8.9 & 34.2 & 6.15 \\
\hline 15 & $\mathrm{M}$ & 153.6 & 13.51 & 35.7 & 10.97 \\
\hline & $\mathrm{F}$ & 148.6 & 8.25 & 32.5 & 7.33 \\
\hline Table 1. Mean and Standard Deviation of Height \& Weight \\
\hline
\end{tabular}

\section{Prevalence of malnutrition}

Table 2 shows the nutritional status among school children. Out of 216 children, 53, 31 and 111 were stunted/severely stunted, underweight/severely underweight, and thin/very thin, respectively. The results highlighted the higher prevalence of malnutrition among younger children.

\begin{tabular}{|c|c|c|}
\hline & Number & Percent \\
\hline \multicolumn{3}{|c|}{ Height for age $(\mathrm{N}=216)$} \\
\hline Normal & 163 & 75.46 \\
\hline Stunted & 39 & 18.06 \\
\hline Severely stunted & 14 & 6.48 \\
\hline \multicolumn{3}{|c|}{ Weight for age $(\mathrm{N}=49)^{*}$} \\
\hline Normal & 18 & 36.73 \\
\hline Moderately Underweight & 23 & 46.94 \\
\hline Severely underweight & 8 & 16.33 \\
\hline \multicolumn{3}{|l|}{$\operatorname{BMI}(\mathrm{N}=216)$} \\
\hline Normal & 102 & 47.22 \\
\hline Thin & 59 & 27.31 \\
\hline Very thin & 52 & 24.07 \\
\hline Overweight & 3 & 1.39 \\
\hline
\end{tabular}

Note: *WA was calculated for student's age up to 10 years.

\begin{tabular}{|c|c|c|c|c|c|}
\hline Variable & $\begin{array}{c}\text { Present } \\
\text { N (\%) }\end{array}$ & $\begin{array}{c}\text { Absent N } \\
(\%)\end{array}$ & Total & $\begin{array}{c}\text { Chi } \\
\text { Square }\end{array}$ & $\begin{array}{c}\text { p- } \\
\text { value }\end{array}$ \\
\hline \multicolumn{6}{|c|}{ Religion } \\
\hline Hindu & $\begin{array}{c}38 \\
(46.91)\end{array}$ & $\begin{array}{c}43 \\
(50.08)\end{array}$ & 81 & $\begin{array}{c}15.30 \\
3\end{array}$ & 0.000 \\
\hline Muslim & $\begin{array}{c}29 \\
(21.48) \\
\end{array}$ & $\begin{array}{c}106 \\
(78.52) \\
\end{array}$ & 135 & & \\
\hline \multicolumn{6}{|c|}{ Sex } \\
\hline Male & $26(32.1)$ & $55(67.9)$ & 81 & 0.071 & 0.79 \\
\hline Female & $\begin{array}{c}41 \\
(30.37) \\
\end{array}$ & $\begin{array}{c}94 \\
(69.63) \\
\end{array}$ & 135 & & \\
\hline \multicolumn{6}{|c|}{ Age group } \\
\hline $6-9$ & $7(22.58)$ & $\begin{array}{c}24 \\
(77.42)\end{array}$ & 31 & $\begin{array}{c}10.00 \\
7\end{array}$ & 0.007 \\
\hline $9-12$ & $\begin{array}{c}34 \\
(25.95)\end{array}$ & $\begin{array}{c}97 \\
(74.05)\end{array}$ & 131 & & \\
\hline $12-15$ & $\begin{array}{c}26 \\
(48.15)\end{array}$ & $\begin{array}{c}28 \\
(51.85)\end{array}$ & 54 & & \\
\hline \multicolumn{6}{|c|}{ Father's Occupation } \\
\hline Business & $\begin{array}{c}10 \\
(23.81)\end{array}$ & $\begin{array}{c}32 \\
(76.19) \\
\end{array}$ & 42 & 9.27 & 0.026 \\
\hline Driver & $\begin{array}{c}19 \\
(36.54)\end{array}$ & $\begin{array}{c}33 \\
(63.46)\end{array}$ & 52 & & \\
\hline Skilled & $\begin{array}{c}12 \\
(19.67) \\
\end{array}$ & $\begin{array}{c}49 \\
(80.33) \\
\end{array}$ & 61 & & \\
\hline Unskilled & $\begin{array}{c}26 \\
(42.62)\end{array}$ & $\begin{array}{c}35 \\
(57.38)\end{array}$ & 61 & & \\
\hline \multicolumn{6}{|c|}{ Mother's Occupation } \\
\hline HW & $\begin{array}{c}54 \\
(28.88)\end{array}$ & $\begin{array}{c}133 \\
(71.12)\end{array}$ & 187 & 0.978 & 0.323 \\
\hline Working & $\begin{array}{c}11 \\
(37.93)\end{array}$ & $\begin{array}{c}18 \\
(62.07)\end{array}$ & 29 & & \\
\hline \multicolumn{6}{|c|}{ Type of Family } \\
\hline Nuclear & $\begin{array}{c}55 \\
(29.57)\end{array}$ & $\begin{array}{c}131 \\
(70.43)\end{array}$ & 186 & 1.313 & 0.252 \\
\hline Joint & $12(40.0)$ & $18(60.0)$ & 30 & & \\
\hline \multicolumn{6}{|c|}{ Mother's Education } \\
\hline Ill & $\begin{array}{c}28 \\
(46.67)\end{array}$ & $\begin{array}{c}32 \\
(53.33)\end{array}$ & 60 & $\begin{array}{c}10.25 \\
7\end{array}$ & 0.017 \\
\hline Primary & $7(21.21)$ & $\begin{array}{c}26 \\
(78.79)\end{array}$ & 33 & & \\
\hline
\end{tabular}




\begin{tabular}{|c|c|c|c|c|c|}
\hline Middle & $\begin{array}{c}15 \\
(29.41)\end{array}$ & $\begin{array}{c}36 \\
(70.59)\end{array}$ & 51 & & \\
\hline High & $\begin{array}{c}17 \\
(23.61)\end{array}$ & $\begin{array}{c}55 \\
(76.39)\end{array}$ & 72 & & \\
\hline \multicolumn{6}{|c|}{ No. of family members } \\
\hline $3-4$ & $\begin{array}{c}12 \\
(31.58)\end{array}$ & $\begin{array}{c}26 \\
(68.42)\end{array}$ & 38 & 4.001 & 0.261 \\
\hline $5-6$ & $\begin{array}{c}43 \\
(37.39)\end{array}$ & $\begin{array}{c}72 \\
(62.61)\end{array}$ & 115 & & \\
\hline $7-8$ & $9(23.68)$ & $\begin{array}{c}29 \\
(76.32)\end{array}$ & 38 & & \\
\hline $9-10$ & $3(18.75)$ & $\begin{array}{c}13 \\
(81.25)\end{array}$ & 16 & & \\
\hline \multicolumn{7}{|c|}{ Father's Education } \\
\hline Ill & $\begin{array}{c}16 \\
(35.56)\end{array}$ & $\begin{array}{c}29 \\
(64.44)\end{array}$ & 45 & 10.25 & 7 \\
\hline Primary & $\begin{array}{c}18 \\
(48.65)\end{array}$ & $\begin{array}{c}19 \\
(51.35)\end{array}$ & 37 & & \\
\hline Middle & $\begin{array}{c}15 \\
(27.78)\end{array}$ & $\begin{array}{c}39 \\
(72.22)\end{array}$ & 54 & & \\
\hline High & $\begin{array}{c}18 \\
(22.50)\end{array}$ & $\begin{array}{c}62 \\
(77.50)\end{array}$ & 80 & & \\
\hline \multicolumn{7}{|c|}{ Table 3. Association of Stunting with } \\
Sociodemographic Variable & \\
\hline
\end{tabular}

Note: Mothers=65, because 2 students' mothers expired.

Multivariate analysis of selected variables revealed that Illiterate mothers were 2.83 times and fathers who had education at primary level were 3.26 times more likely to have stunted children. Stunting was significantly more pronounced in higher age group, 3.18 times in the age group of 12-15 years compared to children in their age group of 6-9 years. The children of fathers working as unskilled workers were found 2.37 times more at risk to become stunted [Table-4].

\begin{tabular}{|c|c|c|c|c|}
\hline Variable & $\begin{array}{c}\text { Present } \\
(\mathrm{N}=67)\end{array}$ & $\begin{array}{c}\text { Absent } \\
(\mathrm{N}=149)\end{array}$ & $\begin{array}{l}\text { Odds } \\
\text { Ratio } \\
\end{array}$ & p-value \\
\hline \multicolumn{5}{|l|}{ Age group } \\
\hline Age 6-9n & 7 & 24 & 1 & \\
\hline Age 9-12 & 34 & 97 & 1.2 & 0.698 \\
\hline Age 12-15 & 26 & 28 & 3.18 & 0.023 \\
\hline \multicolumn{5}{|l|}{ Father's occupation } \\
\hline Self-employedn & 10 & 32 & 1 & \\
\hline Driver & 19 & 33 & 1.84 & 0.187 \\
\hline Skilled & 12 & 49 & 0.78 & 0.615 \\
\hline Unskilled & 26 & 35 & 2.24 & 0.052 \\
\hline \multicolumn{5}{|l|}{ Mother's Education* } \\
\hline Ill & 28 & 32 & 2.83 & 0.006 \\
\hline Primary & 7 & 26 & 0.87 & 0.786 \\
\hline Middle & 15 & 36 & 1.34 & 0.721 \\
\hline Highn & 17 & 55 & 1 & \\
\hline \multicolumn{5}{|l|}{ Father's Education } \\
\hline Ill & 16 & 29 & 1.9 & 0.118 \\
\hline Primary & 18 & 19 & 3.26 & 0.005 \\
\hline Middle & 15 & 39 & 1.32 & 0.487 \\
\hline Highn $^{n}$ & 18 & 62 & 1 & \\
\hline \multicolumn{5}{|c|}{ Note: ${ }^{*}$ Mothers $=65$, as 2 students' mothers expired } \\
\hline \multicolumn{5}{|c|}{ n Reference group } \\
\hline $\begin{array}{r}\text { Table } 4 . \\
\text { Soci }\end{array}$ & $\begin{array}{l}\text { ultivar } \\
\text { demog }\end{array}$ & $\begin{array}{l}\text { te Analy } \\
\text { phic Va }\end{array}$ & $\begin{array}{l}\text { of Stunt } \\
\text { ble }\end{array}$ & ing with \\
\hline
\end{tabular}

\section{DISCUSSION}

\section{Mean Height and Weight}

As shown in Table-1, the anthropometric measurements such as weight and height were found to be more in girls than in boys in all the age groups except in age 14 and 15 where mean height and weight of boys exceeded than that of girls which is in conformity with WHO growth reference values. The present observations were found to be comparable to other studies from similar socioeconomic conditions.[12,13,14,9,15] However, unlike the present findings studies done in other parts of the country showed that boys were heavier and taller than girls till the age of 10 years. From the age of 11 onwards, the mean height and weight of girls exceeded that of boys and similarly in another study in the age group of 13-14 years. ${ }^{[12,10]}$

In contrast to the present findings in a study done in semi-urban regions of Gujarat among 10-14 years school children the BMI was found to be $16.4 \pm 3.3$ and $16.6 \pm 3$ among the boys and girls respectively.[15]

The present study shows no significant differences in mean of height and weight of both boys and girls in same age groups except in at 10 years of age in which the heights of girls have significantly higher values than boys $(\mathrm{t}=2.04$ $p=0.05$ ). However, the differences in heights of the boys in between the age groups was found to be significant as in 8-9 years $(t=4.52, p=0.01), 10-11$ years $(t=3.10, p=0.003), 11-12$ years $(t=4.24, p=0.0001)$, Similarly, in case of girls significant differences in heights were observed in 9-10 years $(t=3.51$, $\mathrm{p}=0.001)$ and 11-12 years $((\mathrm{t}=2.70, \mathrm{p}=0.009)$. Likewise, differences in weights of both boys and girls in between the age groups was found to show similar trend such as in girls 910 years $(\mathrm{t}=3.05, \mathrm{p}=0.004)$ and $11-12$ years $(\mathrm{t}=3.64$, $p=0.0007)$ of age groups whereas in case of boys it was in 8-9 years $(\mathrm{t}=2.83, \mathrm{p}=0.047), 10$ - 11 years $(\mathrm{t}=2.25, \mathrm{p}=0.03)$ and 11 12 years $(t=4.26, p=0.0001)$ age groups respectively.

This could be due to beginning of pubertal growth spurt in girls than boys.[16] Similarly, studies conducted in Assam and in other parts of the country showed that the mean height of girls are higher at the ages $10,11,12 .{ }^{[9,17,11]}$

Similar prevalence of malnutrition is reported from a study done among Jenukuruba tribal children reported $45.2 \%$ of children as having moderate underweight and $14.8 \%$ as having severe underweight. ${ }^{[18]}$ Another study in the villages of Dharwad and Haliyal taluks reported $44.4 \%$ of children as underweight, ${ }^{[19]}$ which is similar to the present study. Similar higher prevalence of $59.9 \%$ was reported among tea garden population of Assam..20] One of the larger studies[21] of anthropometric status of rural school children in low income countries (Ghana, Tanzania, Indonesia, Vietnam and India) found the overall prevalence of underweight to be high in all five countries, ranging from 34 to $62 \%$ for underweight.

Prevalence of stunting and severe stunting in our study was $18.06 \%$ and $6.48 \%$ respectively. Similar prevalence of stunting as $19.8 \%$ and $17.9 \%$, comparable to our study were reported by other authors.[22,23] In a study among Lodha tribal children ${ }^{[24]}$ in a village of Paschim Medinipur, 9.7\% children were found to be severely stunted which is similar to the present study.

Similar prevalence of thinness as $29 \%$ compared to our study. ${ }^{[25]}$ However, in a study in Assam higher prevalence of thinness was found to be $53.9 \%$ among the tea garden workers.[13] 


\section{Association of Height for Age with Other Socio- demographic Variables}

From table-3, it is observed that boys were found to be more stunted than girls but the difference was not significant. In contrast to this in another study significant difference was observed in prevalence among the boy than in girls.[8] Analysis showed no significant difference in prevalence of stunting in children living in joint than in nuclear type of family and on number of family members. However, there was significant association of stunting with father and/or mother educational attainment and occupation of father [Table-3]. The children belonging to Hindu family suffered more from stunting probably because in the studied population most of these families were from lower socioeconomic status and both parents had low level of education compared to children from Muslim family. Association of religion with malnutrition is not reported by other authors. So comparison could not be done on the present finding. Similar findings are reported by other authors from different settings.

\section{CONCLUSION}

During the recent years there have been an unprecedented number of interlinked global declarations and commitments to nutrition. The Decade of Action on Nutrition, adopted by the United Nations General Assembly in 2016, reinforces countries' commitment to achieve by 2025 the global nutrition targets adopted by the Member States of the World Health Organization. As found in the present study, the differences in the degree of growth failure in weight and height have implications for assessing the true prevalence of chronic malnutrition. Height for-age reflects achieved linear growth, and its deficits (stunting) indicate long-term cumulative inadequacies of health and nutrition.[26] Stunting of older children is a legacy of nutritional deprivation during early childhood.[27] This is also important for monitoring trends or evaluating the effects of interventions.[2,28]

Considering malnutrition in all its forms it requires urgent steps to improve malnutrition amongst the school children as Poor nutrition of children not only adversely affects the cognitive development of children, but also likely to reduce the work capacity in future.

\section{Limitation of Study}

The present study was conducted in rural school children from semi-urban area. Hence, further such studies in different population groups are required to conform the present findings and specific multipronged intervention models are to be designed to address the menace of malnutrition in south districts of Assam.

\section{REFERENCES}

[1] WHO-SEARO: adolescent nutrition: a review of the situation in selected South-East Asian Countries, New Delhi: WHO. 2006.

[2] Anurag S, Syed EM, Payal MS, et al. Nutritional status of school-age children-a scenario of urban slums in India. Archives of Public Health 2012;70(1):8.

[3] World Health Organization: research to improve implementation and effectiveness of school health programmes. WHO, Geneva: 1996;1:9-15.
[4] Shivaprakash NC, Joseph RB. Nutritional status of rural school-going children (6-12 years) of Mandya District, Karnataka. Int J Sci Stud 2014;2(2):39-43.

[5] International Food Policy Research Institute. Global nutrition report 2016: from promise to impact: ending malnutrition by 2030. Washington, DC: 2016.

[6] Spear BA. Adolescent growth and development. J Am Diet Assoc 2002;102(3 Suppl):S23-9.

[7] Mandal S, Prabhakar VR, Parthasarathi R, et al. An assessment of nutritional status of children aged 0-14 years in a slum area of Kolkata. International Journal of Medicine and Public Health 2014;4(2):159-62.

[8] Panigrahi A, Das SC. Undernutrition and its correlates among children of 3-9 years of age residing in slum areas of Bhubaneswar, India. Scientific World Journal Article ID 719673, 2014;2014: p. 9.

[9] Manna PK, De Debasis, Bera TK, et al. Anthropometric assessment of physical growth and nutritional status among school children of North Bengal. Anthropologist 2011;13(4):299-305.

[10] Saheb SY, Prasad MR. Physical growth and nutritional status of the Lambadi children of Andhra Pradesh. Anthropologist 2009;11(3):195-206.

[11] Panda P, Benjamin AI, Singh S, et al. Health status of school children in Ludhiana City. Indian Journal of Community Medicine 2000;25(4):150-5.

[12] Sing MB, Haldiya KR, Yadav SP, et al. Nutritional status of school children of salt-workers in Rajasthan. Indian J Med Res 1996;103:304-9.

[13] Medhi GK, Barua A, Mahanta J. Growth and nutritional status of school age children (6-14 Years) of tea garden worker of Assam. J Hum Ecol 2006;19(2):83-5.

[14] Chelleng PK, Mahanta J. Growth and development of tea garden children of Assam (1-12 years). J Hum Ecol 1998;9(4):399-401.

[15] Prema PP, Pinal PP, Anuradha VK. Assessment of nutritional status of school going children in Gujarat. Int J Food Nutr Sci 2016;3(5):1-3.

[16] Aneja S. Nutritional concerns in adolescence. In: Gupte S. edr. Recent advances in pediatrics. New Delhi: Jaypee Brothers 1997:415-28.

[17] Medhi GK, Hazarika NC, Mahanta J. Nutritional status of adolescents among tea garden workers. Ind J Pediatr 2007;74(4):343-7.

[18] Prabhakar JSC, Gangadhar MR. Nutritional status of Jenukuruba tribal children in Mysore district, Karnataka. Anthropologist 2009;11(2):83-8.

[19] Chandra KR, Padennavar UM, Sadashivappa T, et al. Nutrition assessment survey of school children of Dharwad and Haliyal taluks, Karnataka state, India. Kathmandu Univ J Sci Engg Technol 2006;2:1-19.

[20] Medhi GK, Hazarika NC, Shah B, et al. Study of health problems and nutritional status of tea garden population of Assam. Ind J Med Sci 2006;60(12):496505.

[21] Partnership for Child Development. The anthropometric status of school children in five countries in the partnership for child development. Proc Nutr Soc 1998;57(1):149-58. 
[22] Selvaraj V, Sangareddi S, Velmurugan L, et al. Nutritional status of adolescent school children in a semi-urban area based on anthropometry. Int J Contemp Pediatr 2016;3(2):468-72.

[23] Chowdhary SD, Chakraboraty T, Ghosh T. Prevalence of under nutrition in Santal children of Puriliya district, West Bengal. Indian Pediatrics 2008;45(1):436.

[24] Bisai S, Bose K, Ghosh A. Nutritional status of Lodha children in a village of Paschim Medinipur District, West Bengal. Indian J Public Health 2008;52(4):203-6.

[25] Fazili A, Mir AA, Pandit IM, et al. Nutritional status of school age children (5-14 years) in a rural health block of North India (Kashmir) Using WHO Z-Score System. Online J Health Allied Scs 2012;11(2):1-3.
[26] WHO: Physical status: the Use and interpretation of anthropometry. WHO Technical Report Series, 854. WHO, Geneva. 1995.

[27] Medhi GK, Mahanta J. Breast feeding and weaning practices and nutritional status of infants of tea garden workers of Assam. Indian Pediatr 2004;41(12): 1277-9.

[28] Nutrition Foundation of India. Towards better nutrition - problems and policies. In: Gopalan C, Kaur H. edss. Vol. 9. Special Publication Series. Cornell University: 1993:70-8. 